\title{
Pendidikan Kesehatan Kehamilan Resiko Tinggi Di Desa Ringinpitu Kecamatan Plemahan
}

\author{
Susanti Tria Jaya ${ }^{1^{*}}$,Vide Bahtera Dinastiti ${ }^{2}$ \\ ${ }^{1,2}$,STIKES Pamenang, Indonesia \\ santiandi1401@gmail.com
}

\begin{abstract}
ABSTRAK
Pengetahuan kader dan ibu hamil tentang kehamilan resiko memberikan kontribusi dalam pengawasan kehamilan ibu hamil resiko tinggi. Pendampingan kader terhadap ibu hamil resti sangat dibutuhkan dalam mencegah terjadinya keterlambatan penanganan kesehatan oleh tenaga medis dan pendidikan kesehatan selama kehamilan pada ibu hamil resti sangat dibutuhkan untuk membantu ibu hamil memahami kondisi kehamilannya. Tujuan pengabdian ini adalah untuk memfasilitasi mahasiswa dalam memberikan edukasi dan meningkatkan pengetahuan kader kesehatan dan ibu hamil resiko tinggi ibu tentang kehamilan resiko tinggi. Metode yang diberikan menggunakan media LCD dan buku KIA. Hasil pengabdian didapatkan pada akhir pengabdian seluruh kader kesehatan dan ibu hamil resiko tinggi memiliki pengetahuan baik $100 \%$. Peningkatan pengetahuan ini karena kader kesehatan dan ibu hamil resiko tinggi didampingi secara intensif oleh mahasiswa bidan dalam memberikan pendidikan kesehatan, kader kesehatan dan ibu hamil resiko tinggi lebih fokus pada saat edukasi dan dapat menemukan solusi masalah kehamilan resiko tinggi.
\end{abstract}

Kata Kunci: Pendampingan Kader, Peningkatan Pengetahuan, Ibu Hamil

\section{PENDAHULUAN}

Desa Ringinpitu merupakan bagian wilayah Kecamatan Plemahan Kabupaten Kediri dan termasuk Type Desa Swakarya, merupakan desa Siaga Pratama. Jumlah penduduk yang tinggal di Desa Ringinpitu sejumlah 2.199 Orang. Data kesehatan pada tahun 2019, di desa Ringinpitu terdapat 4,6 \% ibu hamil dengan anemia dan 9,3\% ibu hamil dengan KEK dari 42 kehamilan, kelahiran BBLR sebesar 2,6\% dari jumlah kelahiran hidup 38 bayi dan 1 kematian bayi di Desa Ringinpitu. Jumlah kader kesehatan 20 orang. Jumlah ibu hamil pada bulan januari 2020 adalah 19 orang dengan 9 orang diantaranya masuk kategori ibu hamil resti/resiko tinggi. Secara garis besar, kelangsungan suatu kehamilan sangat bergantung pada keadaan dan kesehatan ibu, plasenta dan keadaan janin. Jika ibu sehat dan didalam darahnya terdapat zat-zat makanan dan bahan-bahan organis dalam jumlah yang cukup, maka pertumbuhan dan perkembangan bayi dalam kandungan akan berjalan baik. Dalam kehamilan, plasenta akan berfungsi sebagai alat respiratorik, metabolik, nutrisi, endokrin, penyimpanan, transportasi dan pengeluaran dari tubuh ibu ke 
tubuh janin atau sebaliknya. Jika salah satu atau beberapa fungsi di atas terganggu, maka pertumbuhan janin akan terganggu. Demikian juga bila ditemukan kelainan pertumbuhan janin baik berupa kelainan bawaan ataupun kelainan karena pengaruh lingkungan, maka pertumbuhan dan perkembangan janin dalam kandungan dapat mengalami gangguan. Kelas Ibu hamil yang dimiliki desa Ringinpitu berupakan salah satu upaya untuk memberikan pendidikan kesehatan terhadap ibu hamil, yang pelaksanaannya juga melibatkan peran kader. Kader kesehatan membantu bidan desa dalam mendata ibu hamil diwilayahnya dan mendampingi ibu hamil selama proses kehamilannya.

Kehamilan risiko tinggi menurut Poedji Rochjati adalah kehamilan dengan satu atau lebih satu faktor risiko, baik dari pihak ibu maupun janinnya yang memberi dampak kurang menguntungkan baik bagi ibu maupun janinnya, memiliki risiko kegawatan tetapi tidak darurat. ${ }^{1}$ Pendekatan pada perawatan ibu hamil merupakan upaya yang harus dilakukan berkesinambungan melalui peningkatan kesehatan ibu hamil secara promotif, preventif, kuratif, rehabilitatif. ${ }^{2}$ Adanya potensi risiko kehamilan dan persalinan kemungkinan akan berpengaruh terhadap risiko terjadinya komplikasi dan atau kegawatan pada persalinan juga dapat dipengaruhi oleh derajat faktor risiko. Apabila semakin tinggi tingkatan risiko faktor risiko pada ibu hamil maka semakin tinggi juga ibu komplikasi yang akan dialami. Selain itu, faktor predisposisi juga dapat mempengaruhi tingkat risiko kehamilan antara lain pengetahuan dan faktor sosial ekonomi. ${ }^{3}$

Setiap ibu hamil memerlukan pengawasan saat kehamilan mengingat setiap kehamilan memiliki resiko meskipun di awal kehamilan menunjukkan kondisi normal. Hal ini menunjukkan pengawasan selama kehamilan dan deteksi dini sangat penting dilakukan oleh tenaga kesehatan dalam perencanaan tindak lanjut agar dapat meminimalkan risiko pada ibu atau janin. ${ }^{5}$ Adanya kegiatan ini, kader dapat meningkatkan pengetahuan dalam pendampingan ibu hamil resiko tinggi dalam menjalani proses kehamilannya dan membantu bidan dalam mendeteksi ibu hamil resti.

Oleh sebab itu sebagai salah satu tugas dosen dalam melaksanakan Tri dharma perguruan tinggi, maka kami melakukan pendidikan kesehatan pada kader kesehatan dan ibu hamil resiko tinggi dalam memberikan edukasi untuk meningkatkan pengetahuan kader kesehatan dan ibu hamil resiko tinggi tentang kehamilan resiko tinggi di desa Ringinpitu. Luaran yang diharapkan adalah ibu dapat meningkatkan pengetahuan dan sikap para kader kesehatan dan ibu hamil resiko tinggi tentang kehamilan resiko tinggi.

\section{Tujuan Umum}

Dengan terselenggaranya kegiatan ini diharapkan dapat meningkatkan pengetahuan dalam pendampingan ibu hamil resiko tinggi dalam menjalani proses kehamilannya dan membantu bidan dalam mendeteksi ibu hamil resti.

\section{Tujuan Khusus}

Adapun tujuan khsusus dari kegiatan ini adalah :

a. Menambah pengetahuan kader kesehatan dan ibu hamil resiko tinggi tentang kehamilan resiko tinggi

b. Memperbaiki sikap kader kesehatan dan ibu hamil resiko tinggi terhadap kehamilan resiko tinggi

c. Meningkatkan pengetahuan siswa dalam memberikan edukasi pada kader kesehatan dan ibu hamil resiko tinggi dan penggunaan buku KIA agar memudahkan kader kesehatan dan ibu hamil resiko tinggi meningkatkan pengetahuan tentang kehamilan resiko tinggi 


\section{Sasaran}

Sasaran dalam kegiatan ini adalah kader kesehatan dan ibu hamil resiko tinggi di Desa Ringinpitu.

\section{BAHAN DAN METODE}

Strategi pelaksanaan pengabdian masyarakat ini dilakukan secara sistematis. Kegiatan ini

dimulai dari kegiatan besar praktik kebidanan komunitas yang merupakan bagian dari pembelajaran Asuhan Kebidanan komunitas. Dalam kegiatan tersebut kemudian dibagibagi menjadi berbagai kegiatan yang salah satunya adalah pendidikan kesehatan pada kader kesehatan dan ibu hamil resiko tinggi tentang kehamilan resiko tinggi. Desain yang digunakan adalah model edukasi tatap muka dengan media LCD dan buku KIA. Waktu pelaksanaannya dilakukan pada bulan Januari 2020 di Desa Ringinpitu.

Pada awal kegiatan mahasiswa melakukan pendataan tentang kesehatan ibu dan anak di masyarakat. Mahasiswa kemudian melakukan survey jumlah subjek kader kesehatan dan ibu hamil resti yang akan diberikan pendidikan kesehatan. Mahasiswa melakukan kontak dengan kader kesehatan dan ibu hamil resti dan melakukan penjadwalan dilakukannya pendidikan kesehatan secara bersama - sama. Pada saat pelaksanaan, mahasiswa didampingi oleh dosen dalam melakukan pendidikan kesehatan. Dosen menilai apakah pendidikan kesehatan yang telah diberikan sudah sesuai atau perlu ditambahkan lagi. Pendidikan kesehatan yang dilakukan sebanyak dua kali menggunakan media LCD dan yang ada di dalam buku KIA. Pendidikan kesehatan tentang ibu hamil resti meliputi: kategori ibu hamil resiko tinggi, tanda bahaya kehamilan, faktor yang berhubungan dengan komplikasi kehamilan dan cara deteksi kehamilan resiko tinggi.

\section{HASIL}

Pendidikan Kesehatan tentang Kehamilan Resiko Tinggi pada kader kesehatan dan ibu hamil resti dilaksanakan dilaksanakan pada tanggal 6-24 Januari 2020. Proses pelaksanaan bersama dengan mahasiswa yang ikut dalam pengabdian. Mahasiswa lebih berperan dalam kegiatan pengabdian masyarakat dengan memberikan pendidikan kesehatan pada kader dan ibu hamil resti. Sebelum diberikan materi, kader dan ibu hamil resti kuesioner tentang kehamilan resiko tinggi. Berikut merupakan hasil dari pengukuran pengetahuan kader dan ibu hamil resti di Desa Ringinpitu:

Tabel 1. Hasil pengukuran pengetahuan tentang kehamilan resiko tinggisebelum dilakukan pendidikan kesehatan di Desa Ringinpitu

\begin{tabular}{ccc}
\hline Pengetahuan & Frekuensi & $\%$ \\
\hline Baik & 0 & 0 \\
\hline Cukup & 23 & 79 \\
\hline Kurang & 6 & 21 \\
\hline Total & 29 & 100
\end{tabular}

Pada tabel 1 didapatkan bahwa sebagian besar kader kesehatan dan ibu hamil resti berpengetahuan menengah 23 orang (79\%), sedangkan sisanya berpengetahuan rendah 6 orang (21\%). Materi disampaikan sesuai dengan yang terdapat di dalam buku KIA. Kegiatan ini dilakukan dengan mengumpulkan seluruh kader kesehatan dan ibu hamil resti di balai desa Ringinpitu. Di akhir sesi pendidikan kesehatan kader 
kesehatan dan ibu hamil resti di minta mengisi kuesioner pengetahuan tentang tentang kehamilan resiko tinggi dan diberikan lembar evaluasi program yang telah dilaksanakan.

Tabel 2. Hasil pengukuran pengetahuan tentang tentang kehamilan resiko tinggi setelah dilakukan pendidikan kesehatan di Desa Ringinpitu

\begin{tabular}{ccc}
\hline Pengetahuan & Frekuensi & $\%$ \\
\hline Baik & 29 & 100 \\
\hline Cukup & 0 & 0 \\
\hline Kurang & 0 & 0 \\
\hline Total & 29 & 100 \\
\hline
\end{tabular}

Pada tabel 2 didapatkan bahwa semua kader kesehatan dan ibu hamil resti berpengetahuan baik 29 orang (100\%). Hasil ini kemudian dilakukan sebagai evaluasi pendidikan kesehatan tentang kehamilan resiko tinggi yang telah diberikan.

\section{PEMBAHASAN}

Materi yang diberikan dari buku KIA adalah pendidikan kesehatan tentang kehamilan resiko tinggi, tanda bahaya dan Kartu Skor Pudji Rochyati (KSPR). ${ }^{6}$ Pendidikan kesehatan ini adalah bentuk kegiatan pengabdian masyarakat yang bertujuan untuk meningkatkan pengetahuan kader kesehatan dan ibu hamil resiko tinggi tentang kehamilan resiko tinggi agar dapat memahami kondisi kesehatan pada kehamilan resiko tinggi dan bagaimana tindakan yang harus dilakukan untuk mencegah terjadinya komplikasi, yaitu segera kontak dengan tenaga kesehatan yang ada di desa Ringinpitu. Dasar dilakukan kegiatan ini karena adanya ibu hamil resiko tinggi yang belum paham mengenali tentang tanda-tanda ibu hamil yang beresiko tinggi, pada tahun 2019 terdapat 4,6 \% ibu hamil dengan anemia dan 9,3\% ibu hamil dengan KEK dari 42 kehamilan, dan kelahiran BBLR sebesar 2,6\% dari jumlah kelahiran hidup 38 bayi, dan 1 kematian bayi di Desa Ringinpitu.

Hal ini sesuai dengan penelitian Meyliya dan Seventina (2016) dengan adanya pengetahuan yang baik tentang kehamilan resiko tinggi maka ibu hamil akan lebih mengenali dan mencegah sedini mungkin penyulit atau masalah dalam kehamilan. Pengetahuan yang baik akan membawa persepsi yang baik bagi seseorang meskipun dapat berbeda dari kenyataan yang obyektif. Diharapkan dengan persepsi ibu hamil tentang kehamilan resiko tinggi yang baik akan dapat mengubah pola pikir, perilaku dan sikap untuk mencegah, menghindari dan mengatasi resiko kehamilan. ${ }^{7}$

Desa ringinpitu dalam program kegiatan komunitas mahasiswa merupakan salah kegiatan yang dapat menjembatani pengetahuan kader kesehatan dan ibu hamil resti melalui pendidikan kesehatan dari memberdayakan calon tenaga kesehatan khususnya mahasiswa kebidanan. Adanya program ini dapat meningkatkan pengetahuan kader kesehatan dan ibu hamil resti dan juga menambah pengalaman belajar mahasiswa. Dosen berperan sebagai pendamping dalam pelaksanaannya. Hasil yang diperoleh bahwa pada akhir pendidikan kesehatan kehamilan resiko tinggi didapatkan seluruh kader kesehatan dan ibu hamil resti meningkat pengetahuannya menjadi baik (100\%). Hal ini menunjukkan kegiatan pendidikan kesehatan kehamilan resiko tinggi terbukti efektif dalam meningkatkan pengetahuan kader kesehatan dan ibu hamil resti tentang kehamilan resiko tinggi. 


\section{KESIMPULAN}

Kegiatan pendidikan kesehatan tentang kehamilan resiko tinggi pada kader kesehatan dan ibu hamil resti merupakan suatu sarana bagi dosen mahasiswa, dan masyarakat untuk menjembatani teori tentang kehamilan resiko tinggi. Kegiatan ini dapat memfasilitasi mahasiswa untuk belajar memberikan pendidikan kesehatan yang tepat langsung pada klien. Sedangkan pada kader kesehatan dan ibu hamil resti mendapatkan pengetahuan langsung dan didampingi oleh calon tenaga kesehatan untuk meningkatkan pengetahuan tentang kehamilan resiko tinggi. Diharapkan kedepannya kegiatan pendidikan kesehatan tentang kehamilan resiko tinggi ini dapat berlanjut dan menjadi program rutin memberdayakan calon tenaga kesehatan untuk terjun langsung membantu masalah kesehatan tentang kehamilan resiko tinggi, sehingga permasalahan yang ada dapat diatasi.

\section{DAFTAR PUSTAKA}

1. Prasetyo B, Had SN. (2013). Penerapan antenatal terpadu pada ibu hamil di wilayah kerja Puskesmas Sumobito Kabupaten Jombang.

2. Ambarwati, Maria Retno, Rita Yuliana, Nurwening Tyas Wisnu. (2011). Gambaran Faktor Penyebab Ibu Hamil Resiko Tinggi Tahun 2005-2010 di Polindes Sambikerep Kecamatan Rejoso Kabupaten Nganjuk. Jurnal Penelitian Kesehatan Suara Forikes. Volume II Nomor Khusus Hari Kesehatan Nasional. ISSN: 2086-3098

3. Prawirohardjo, Sarwono. (2010). Ilmu Kebidanan. Jakarta: Yayasan Bina Pustaka Sarwono Prawirohardjo

4. Nissa AA, Surjani, Mardiyaningsih E. (2013).Gambaran kepuasan ibu hamil terhadap pelayanan antenatal care di Puskesmas Getasan Kebupaten Semarang. Jurnal Keperawatan Maternitas. 2013;1(1):21-7

5. Coco L. (2014). Management of high-risk pregnancy. Minerva Ginecologica. 2014;66 (4):383-9.

6. Kemenkes RI. ( 2015). Buku Kesehatan Ibu dan Anak. Jakarta: Kemenkes RI

7. Meyliya, Qudriani dan Seventina, Nurul Hidayah. (2017). Persepsi Ibu Hamil Tentang Kehamilan Resiko Tinggi Dengan Kepatuhan Melakukan Antenatal Care Di Desa Begawat Kecamatan Bumijawa Kabupaten Tegal Tahun 2016. Seminar Nasional IPTEK Terapan (SENIT). 